\title{
Effect of a phytogenic feed additives mixture on milk physico-chemical properties and biochemical parameters of Holstein cows
}

\section{Daiane Kosinski Paglia ${ }^{1}$ (D) Silvana Giacomini Collet ${ }^{1}$ (D) Giovana Camillo ${ }^{1}$ (D) Alan Miranda Prestes ${ }^{1}$ (i) Artur Valerio Cony ${ }^{2}$ (D) Fernanda Maria Pazinato ${ }^{1}$ (D) Lilian Kolling Girardini ${ }^{*}$ (iD}

${ }^{1}$ Universidade do Oeste de Santa Catarina (UNOESC), 89820-000, Xanxerê, SC, Brasil. E-mail: lilian.kolling@unoesc.edu.br. *Corresponding author.

${ }^{2}$ Médico veterinário, Chapecó, SC, Brasil.

\begin{abstract}
This study aimed to analyze the effect of phytogenic additives based on cardol, cardanol, and ricinoleic acid on the physicochemical qualities and biochemical parameters of Holstein cow milk. Nineteen animals were divided into the control (GI) and treatment (GII) groups. Prior to the beginning of the experiment, sodium monensin was removed from the feed provided to the animals. This study consisted of two phases. In the first, animals from GI received the standard diet, without additives, while animals from GII received the standard diet supplemented with $10 \mathrm{~g}$ of phytogenic additives for 60 days. At the end of the first stage, the animals remained 30 days without receiving additives and in the second phase the groups were inverted, and the GII again received the phytogenic additive during the subsequent 60 days. Physical-chemical analyzes of milk were performed at moments 0,15,30,45 and 60 days of the experiment and the blood parameters at times 0 and 60 days of the experiment were evaluated. There was no significant difference for the treatment $x$ time interaction in any of the variables, but there was a trend between groups for the CCS parameter and there was a statistical difference for the protein, as well as for the AST. In this study it is observed that the addition of phytogenic additive modulating rumen fermentation based on cardol, cardanol and ricinoleic acid does not compromise, in general, the quality of milk, with positive results for some specific parameters such as protein content and aminotransferase.
\end{abstract}

Key words: biochemical profile, dairy cattle, milk quality, phytogenic additive.

Efeito de uma mistura de aditivos fitogênicos alimentares nas propriedades físico-químicas do leite e parâmetros bioquímicos de vacas leiteiras da raça holandês

RESUMO: Esse estudo teve por objetivo avaliar o efeito de um aditivo fitogênico a base de cardol, cardanol e ácido ricinoléico na qualidade fisico-quimica do leite e perfil bioquimico de vacas da raça Holandês. Dezenove animais foram divididos em dois grupos: Grupo Controle (GI) e Grupo Tratado (GII). Previamente ao início do experimento, retirou-se a monensina sódica da ração fornecida aos animais. Este estudo consistiu de duas fases, sendo que na primeira fase, os animais do GI receberam a dieta padrão, sem aditivos, enquanto os animais do grupo GII receberam a ração padrão suplementada com $10 \mathrm{~g}$ dos aditivos fitogênicos durante 60 dias. Ao final da primeira etapa, os animais permaneceram 30 dias sem receber aditivos e na segunda fase os grupos foram invertidos, sendo que o GII novamente recebeu o aditivo fitogênico durante os 60 dias subsequentes. Foram realizadas análises físico-químicas do leite nos momentos 0, 15, 30, 45 e 60 dias do experimento e avaliados os parâmetros sanguineos nos momentos 0 e 60 dias do experimento. Não se observou diferença significativa para a interação tratamento x tempo em nenhuma das variáveis, mas tendência entre grupos para o parâmetro de CCS, e houve diferença estatística para a proteina, assim como para a AST. Neste estudo observa-se que a adição de aditivo fitogênico modulador de fermentação ruminal a base de cardol, cardanol e ácido ricinoléico não compromete, de forma geral, a qualidade do leite, tendo resultados positivos para alguns parâmetros especificos como teor de proteina e aspartato aminotransferase.

Palavras -chave: aditivo fitogênico, qualidade do leite, perfil bioquímico, bovinos de leite.

\section{INTRODUCTION}

Milk quality is defined by the chemical composition, physicochemical properties, and hygiene parameters. These parameters are influenced by diet, management practices, genetics, and animal breeds, as well as body condition or health status of the animals. Quality and hygiene status of raw milk and dairy products are evaluated based on the standards for human health protection and conservation of the nutritional properties of this food (PICININ et al., 2017). Therefore, the health of cattle and a basic milk quality control are essential to produce innocuous dairy products (SANTOS \& FONSECA, 2019).

The inclusion of food additives is a common practice in ruminant nutrition. This measure 
is adopted as a strategy to promote the efficient use of nutrients by ruminal microorganisms and to minimize losses of energy and protein during fermentation. Among the additives, ionophores have been used with good results to improve the production efficiency of dairy cows (DUFFIELD et al., 2008). But their use is restricted in animal feeding due to reduced public acceptance and increased scientific concern about the safety of their use (JOUANY \& MORGAVI, 2007). Yet, antimicrobials have been widely used in the treatment of infectious cattle disease worldwide. However, uncontrolled antimicrobial use, whether for therapeutic or performance enhancement purposes, has resulted in global concerns on antibiotic resistant bacteria causing severe implications to animal and public health (FAO, 2016). In this context, research on using alternatives to reduce the use of many chemical-based substances in cattle have been widely reported, especially as enhancers of milk production (CALSAMIGLIA et al., 2007; KHOLIF et al., 2020).

Among the alternatives, phytogenic additives have stood out in cow feeding because of antioxidant (OH et al., 2013) and anti-inflammatory properties (OH et al., 2015) and due to the improvement in the quality of milk and maintenance of the physicochemical characteristics of milk without harming the animals' health (BORNEO; AGUIRRE, 2008; PRABHASANKAR et al., 2009; TORRES et al., 2007; KHOLIF et al., 2020).

In addition to their antimicrobial effects, phytogenic additives are considered effective rumen modulators characterized by their anti-inflammatory (VIEIRA et al., 2000), antioxidant (TREVISAN et al., 2006), and gastroprotective properties (HAMAD \& MUBOFU, 2015). In addition, these compounds or classes of additives, generally have an antimicrobial effect and can alter the growth and metabolism of several bacteria, including bacteria present in the rumen, and, consequently, changing ruminal fermentation (WALLACE, 2004). This action occurs through the selection of Gram-negative bacteria and inhibiting the growth of Gram-positive bacteria, a situation that favors the increase of propionate production and reduces the concentrations of acetic acid, lactic acid and methane (SHINKAI et al., 2012).

Phenolic compounds such as anacardic acid, cardanol, and cardol can inhibit the growth of Gram-positive bacteria and promote the proliferation of Gram-negative bacteria, thereby increasing ruminal propionate production (IPHARRAGUERRE \& CLARK, 2003). Studies differ in relation to the effects of using phytogenic additives in the feeding of ruminants. Some authors have reported that phytogenic additives can improve feed efficiency (CRUZ et al., 2014; VALERO et al., 2016), and meat quality of beef cattle (DO PRADO et al., 2016), as well as have demonstrated the productive and physiological responses of lactating dairy cows supplemented with phytogenic feed ingredients (RODRIGUES et al., 2019). According to GANDRA et al. (2014), there was an increase in the milk production of cows that received this phytogenic additive in relation to the control group and a reduction of $2.15 \mathrm{~kg}$ in the CMS, increasing the productive efficiency of the animals. However, the performance of ruminants supplemented with phytogenic additives has no specific response pattern (KHIAOSA-ARD \& ZEBELI, 2013) and the wide variety of compounds and doses used in animal experimentation limits the comparison of results. Much of the studies on the inclusion of phytogenic additives in dairy cow diets were conducted in vitro (KLEVENHUSEN et al., 2012), which makes it difficult to standardize the dosage and fully elucidate the effects of this compound. However, some in vivo studies have been carried out in order to evaluate the effectiveness of these functional oils and their ability to manipulate rumen fermentation and, consequently, improve the use of nutrients and the performance of dairy cows (BENCHAAR et al., 2006; BENCHAAR et al ., 2007). However, these data are insufficient in relation to the research on dairy cattle performance.

The aim of this study was to assess the effect of phytogenic additives based on cardol, cardanol, and ricinoleic acid on the physicochemical properties and the biochemical parameters of Holstein cow milk.

\section{MATERIALS AND METHODS}

\section{Experimental design}

The study was conducted on a dairy farm where a semi-confined system is used. The farm is located in Abelardo Luz County, in the western region of Santa Catarina state, Brazil. Nineteen lactating cows were allocated into two groups (GI: control; GII: treatment). At the beginning of the study, eight cows were primiparous and 11 were multiparous. In addition, according to the animals' milk days, for each time and groups, three categories were created: up to 100 days, between 100 and 200 days, and more than 200 days.

Before the commencement of data collection (30 days), monensin sodium salt was removed from the animal feed. This study consisted of two phases with GI as the control group, comprising of nine animals, and GII as the treatment group of 10 animals. In the first phase, GI animals received 
the standard diet, without any additives, while the animals in the GII group received the standard feed supplemented with $10 \mathrm{~g}(5 \mathrm{~g}$ in the morning and $5 \mathrm{~g}$ in the afternoon) of the phytogenic additives for 60 days of milking. The phytogenic additive was previously weighed and divided into packages, and then supplied individually for each animal. At the end of the 60 days, the animals were not fed with any phytogenic additives for 30 days. In the second phase, the animal groups were swapped. In other words, the animals that were in the GI group were now in the GII group and viceversa. During the second phase, the GII group received $10 \mathrm{~g}$ ( $5 \mathrm{~g}$ in the morning and $5 \mathrm{~g}$ in the afternoon) of the phytogenic additives with the feed for 60 days of milking, completing a total of 150 experimental days.

Milk physico-chemical analyses were performed (standard plate count [SPC], somatic cell count [SCC], protein, fat, lactose, total solids, and urea) and blood parameters (creatinine, urea, aspartate aminotransferase [AST], cholesterol, and gammaglutamyl transferase [GGT]) were evaluated. For these tests, the following schedule was used: milk samples were collected on days $0,15,30,45$, and 60 of each experimental phase, and blood samples were collected on days 0 and 60 of each experimental phase.

\section{Phytogenic additive}

A phytogenic additive composed of ricinoleic acid (castor oil), cardol and cardanol (cashew oil) was used. These have antimicrobial activity, allowing the manipulation of ruminal fermentation, through selective inhibition against Gram positive bacteria, since they cannot penetrate the wall of Gram-negative bactéria because of their hydrophilic characteristic.

Diet

Throughout the experimental period, all animals were fed the same diet, consisting of roughage (corn silage) in the trough (20 kg per day and animal), Jiggs pasture grass, and standard feed. The cattle feed was produced at the farm with the following ingredients: corn kernels $(52 \mathrm{~kg})$, soybean meal (32 kg), soybean kernels (9 kg), mineral salt (5 $\mathrm{kg})$, sodium bicarbonate buffer $(1 \mathrm{~kg})$, and urea (1 kg). The feed was given according to the animals' average production. A bromatological analysis of the feed is described in table 1 . The average milk production per animal ranged from 28 to $35 \mathrm{~L} \mathrm{day}^{-1}$.

\section{Milk physico-chemical analyses}

Milk collection was performed on days 0 , $15,30,45$, and 60. Samples in collecting cups were sent to the laboratory of the Holstein Cattle Breeder Association of Paraná state (Associação Paranaense dos Criadores da Raça Holandês - APCBRH) for SCC, SPC, urea, protein, lactose, fat, and total solids analyses.

The fat, urea, lactose, protein, and total solids analyses were performed using the infrared method, according to the international standard (FIL-IDF Standard No. 141C: 2000). SCC and total bacterial count (TBC) were performed using the flow cytometry assay recommended by IDF Standard 1482: 2006 (International Dairy Federation [IDF], 2006).

\section{Serum biochemical analyses}

For serum biochemical analyses, venipunctures in the coccygeal veins were performed. Blood samples were centrifuged at $3,000 \times g$ for 10 min to obtain the serum specimens, which were stored in microtubes at $-80^{\circ} \mathrm{C}$.

Serum biochemical analyses were performed by using a semi-automatic spectrophotometer (Bio Plus 2000) at the Clinical Pathology Laboratory of the University of West Santa Catarina, Campus Xanxerê. The enzymes AST and GGT and the metabolites cholesterol, creatinine, and urea were analyzed using specific kits from Labtest

Table 1 - Bromatological analysis for the animal diet

\begin{tabular}{|c|c|c|c|c|c|c|}
\hline Sample & PDM & DM & MM & $\mathrm{CP}$ & NDF & $\mathrm{ADF}$ \\
\hline & $(\%)$ & $(\%)$ & ----------- & ------- & 4)-------. & --------- \\
\hline Silage & 48.78 & 92.76 & 5.13 & 6.82 & 41.40 & 23.78 \\
\hline Feed & - & 87.56 & 6.41 & 16.79 & 17.23 & 9.34 \\
\hline Pasture & 18.01 & 91.95 & 8.52 & 21.36 & 69.46 & 31.46 \\
\hline
\end{tabular}

PDM, partial dry matter; DM, dry matter ; MM, mineral matter; $\mathrm{CP}$, crude protein; NDF, neutral detergent fiber; ADF, acid detergent fiber. 
Diagnostica SA, Lagoa Santa, Brazil. The coefficient of variation for each analysis was less than $10 \%$.

\section{Statistical analyses}

The premises of normality and homoscedasticity of the residues were previously tested. When not answered, the data were transformed using the Box-Cox methodology (BOX \& COX, 1964). Results data were subjected to analysis of variance, with repeated measures over time, using the mixed procedure of the SAS (Statistical Analysis System) (CODY, 2018). The fixed effects tests of the model were verified by using $F$-test at $5 \%$ significance level $(P<0.05)$, using the following model:

$$
\mathrm{Y}_{\mathrm{ijkl}}=\mu+\text { GROUP }_{\mathrm{i}}+\text { TIME }_{\mathrm{j}}+\text { DIM }_{\mathrm{k}}+
$$
GROUP $_{i}^{*}$ TIME $_{j}+$ GROUP $_{i}{ }^{*}$ DIM $_{k}+$ REP $_{1}\left(\right.$ GROUP $\left._{\mathrm{i}}\right)$ $+\mathrm{MP}+\mathrm{e}_{\mathrm{ijkl}}$

Where: $\mathrm{Y}_{\mathrm{ijkl}}=$ observed values for the variables; $\mu=$ mean score from several variables; GROUP $_{\mathrm{i}}=$ treatment effect (control and treated); TIME $=$ effect of collecting time (days 0, 15, 30, 45, and 60$) ; \mathrm{DIM}_{\mathrm{k}}=$ effect of the days in milk category (1: $<100$ days, 2: 100-200 days, and 3: $>200$ days).
GROUP $_{i}{ }^{*}$ TIME $_{j}=$ effect of the interaction between treatments and collecting time; GROUP ${ }_{i}{ }^{*} \mathrm{DIM}_{\mathrm{k}}=$ effect of the interaction between treatments and the days in milk category; $\operatorname{REP}_{1}\left(\mathrm{GROUP}_{\mathrm{i}}\right)=$ repetition effect in the treatment (error a); $\mathrm{MP}=$ regression coefficient of the milk production effect for each animal; and $\mathrm{e}_{\mathrm{ijk}}$ is the experimental residual error (error b).

\section{RESULTS AND DISCUSSION}

There was no significant difference between GI and GII groups in SPC, fat, lactose, and urea results for the time parameter (Table 2). However, there was a significant difference in milk quality between the groups, especially for protein, when phytogenic additives based on cardol, cardanol, and ricinoleic acid were used (Table 2). There was a not significant difference for SCC between groups $(P=0.189)$, with real mean values of 264,460 cells $\mathrm{mL}^{-1}$ and 131,290 cells $\mathrm{mL}^{-1}$ in the GI and GII samples, respectively, (Table 2 and Figure 1B). But, this reduction of SCC in GII samples may be associated with the positive effect of phytogenic additives. SCC is a parameter related to the health of the mammary glands

Table 2 - Milk physico-chemical analyses for standard plate count (SPC), somatic cell count (SCC), fat, protein, lactose, and urea of Holstein cows' milk from the control group (GI) and the treated group (GII), who were supplemented with phytogenic additives based on cardol, cardanol, and ricinoleic acid (GII).

\begin{tabular}{|c|c|c|c|c|c|c|c|}
\hline \multirow[t]{2}{*}{ Variant } & \multirow[t]{2}{*}{ Group } & \multirow[t]{2}{*}{ Mean $^{*}$} & \multirow[t]{2}{*}{ SEM } & \multicolumn{4}{|c|}{ 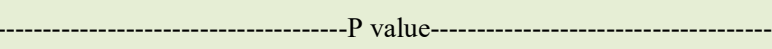 } \\
\hline & & & & Groups x Time & Groups & DIM & DIM x Groups \\
\hline \multirow{2}{*}{$\begin{array}{l}\text { SPC } \\
(\mathrm{CFU} \mathrm{mL}-1)\end{array}$} & GI & 48.54 & 60.00 & \multirow{2}{*}{0.505} & \multirow{2}{*}{0.591} & \multirow{2}{*}{0.726} & \multirow{2}{*}{0.208} \\
\hline & GII & 131.29 & 59.04 & & & & \\
\hline \multirow{2}{*}{$\begin{array}{l}\text { SCC } \\
\text { (cells mL-1) }\end{array}$} & GI & 264.46 & 47.85 & \multirow{2}{*}{0.392} & \multirow{2}{*}{0.189} & \multirow{2}{*}{0.930} & \multirow{2}{*}{0.252} \\
\hline & GII & 150.57 & 47.08 & & & & \\
\hline \multirow{2}{*}{$\begin{array}{l}\text { Fat } \\
(\%)\end{array}$} & GI & 3.91 & 0.11 & \multirow{2}{*}{0.483} & \multirow{2}{*}{0.296} & \multirow{2}{*}{0.1753} & \multirow{2}{*}{0.810} \\
\hline & GII & 3.75 & 0.11 & & & & \\
\hline \multirow{2}{*}{$\begin{array}{l}\text { Protein } \\
(\%)\end{array}$} & GI & $3.20 \mathrm{a}$ & 0.10 & \multirow{2}{*}{0.258} & \multirow{2}{*}{0.023} & \multirow{2}{*}{0.249} & \multirow{2}{*}{0.822} \\
\hline & GII & $2.97 \mathrm{~b}$ & 0.07 & & & & \\
\hline \multirow{2}{*}{$\begin{array}{l}\text { Lactose } \\
(\%)\end{array}$} & GI & 4.27 & 0.04 & \multirow{2}{*}{0.475} & \multirow{2}{*}{0.784} & \multirow{2}{*}{0.051} & \multirow{2}{*}{0.020} \\
\hline & GII & 4.33 & 0.04 & & & & \\
\hline \multirow{2}{*}{$\begin{array}{l}\text { Urea } \\
(\mathrm{mg} \mathrm{dL}-1)\end{array}$} & GI & 18.25 & 0.39 & \multirow{2}{*}{0.852} & \multirow{2}{*}{0.127} & \multirow{2}{*}{0.504} & \multirow{2}{*}{0.407} \\
\hline & GII & 17.41 & 0.39 & & & & \\
\hline \multirow{2}{*}{$\begin{array}{l}\text { Total } \quad \text { solids } \\
(\mathrm{g} / 100 \mathrm{~g})\end{array}$} & GI & 12.30 & 0.15 & \multirow{2}{*}{0.295} & 0.162 & 0781 & 0477 \\
\hline & GII & 11.99 & 0.15 & & & & \\
\hline
\end{tabular}

SEM: standard error of the mean. SPC: standard plate count. SCC: somatic cell count. CFU: colony forming unit. Different letters indicate significant differences between groups $(\mathrm{Pp}<0.05)$. DIM: Days in Milk; ${ }^{*}$ Real mean. 
of cattle, and directly influences the quality of milk and the organoleptic characteristics and shelf life of the dairy products (SANTOS \& FONSECA, 2019).

The effects of Days in Milk (DIM) on milk components (Table 2) were tested, in which a significant difference was observed for the interaction DIM x Groups $(\mathrm{P}<0.020)$ for lactose, in which the animals of the GII had averages of lactose higher than GI, especially within the DIM 1 category. Lactose is one of the constituents of milk with less oscillation, and has a high osmotic capacity, and the greater the secretion of lactose, the greater the volume of milk produced (BOTARO et al., 2011), therefore, an important result of the applicability of additives used in this study.

Thus, these natural phytogenic compounds may be used as additives that have a similar performance to that of monovalent ionophores. Additionally, the phytogenic additives had an anti-inflammatory effect, improving animal performance and decreasing somatic cell counts (CALSAMIGLIA et al., 2007). Similarly, in a study using $10 \mathrm{~g}$ of oregano extract as additives on
32 dairy cows (16 Holstein and 16 crossbred HolsteinGir), significant improvements in increased protein and decreased SCC levels were observed. These results suggest that catechins protect the epithelial tissue of mammary glands from damage due to oxidative processes and, thereby, contribute to the control and prevention of mastitis (KOLLING et al., 2018).

It is also important to point out the effect of SCC on other physico-chemical parameters. In a study involving Holstein and crossbred cows, GONZALEZ et al. (2003) found a significant difference $(\mathrm{P}<0.01)$ in the SCC parameters for protein and fat levels in milk, and increase in SCC led to reduction in protein levels and elevation of fat levels.

Evaluating the results for the SCC parameter, it is observed that there was no statistical difference between the groups. Similarly, BENCHAAR (2016) did not find any change in the fat, protein, and lactose concentrations of milk from cows fed up to $10 \mathrm{~g} \mathrm{day}^{-1}$ of phytogenic additives. Similar to the study by GIANNENAS et al. (2011), this study also did not find any positive effect of a phytogenic additive (oregano) in the animal diet on SCC.
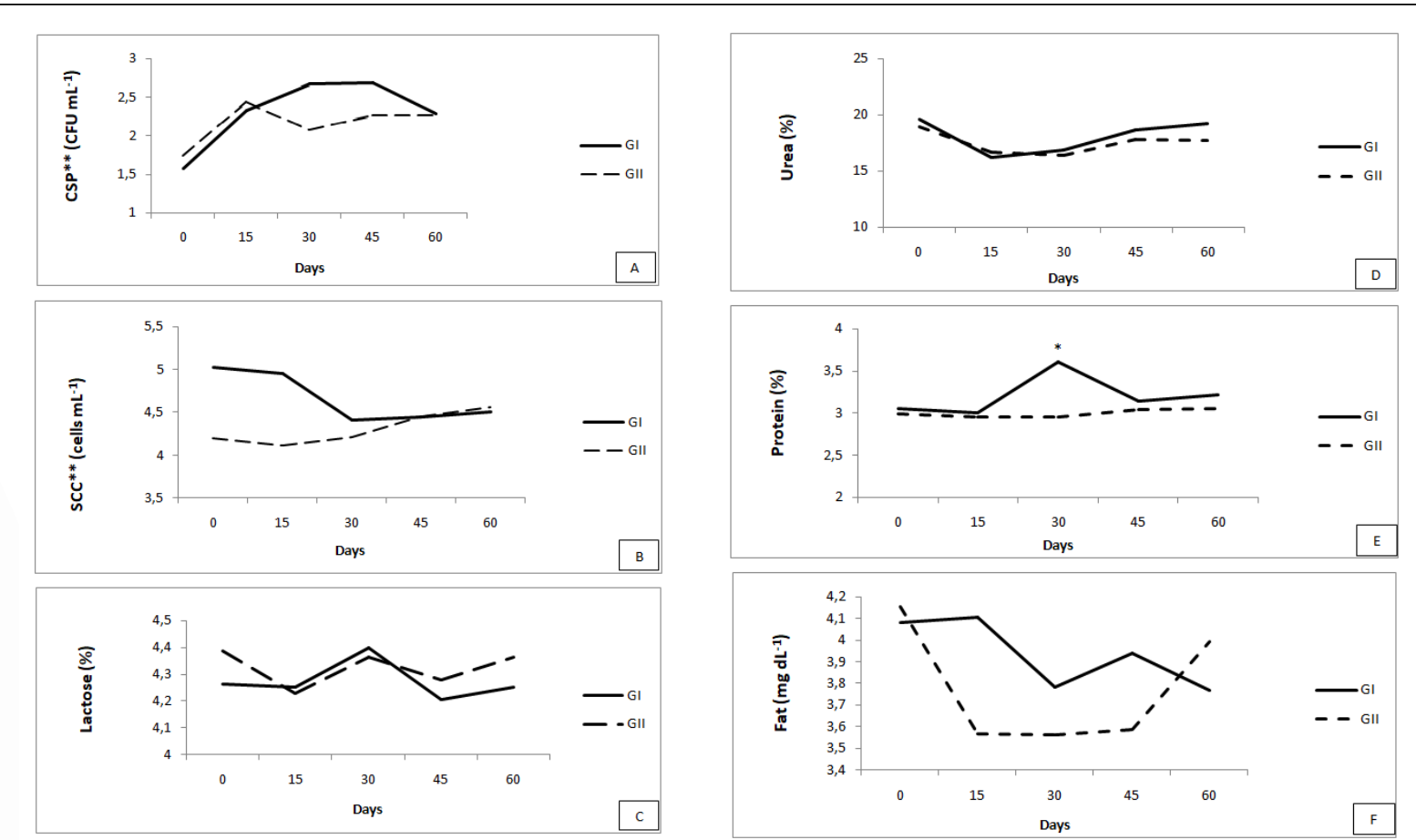

Figure 1 - Milk physico-chemical analyses for GI and GII according to milking day. (A) Standard plate count $\left(\mathrm{CFU} \mathrm{mL}^{-1}\right)$; (B) Somatic cell count (cells $\left.\mathrm{mL}^{-1}\right)$; (C) Lactose (\%); (D) Urea (\%); (E) Protein (\%); and (F) Fat (mg dL ${ }^{-1}$ ); *Significant differences between groups $(\mathrm{P}<0.05)$. ${ }^{* *}$ Data transformed by Box-Cox methodology.

Ciência Rural, v.51, n.12, 2021. 
There was a significant difference between the treatments for protein level $(\mathrm{P}=0.023)$; GI and GII showed mean protein levels of 3.20 and 2.97, respectively, (Table 2 and Figure 1e). The animals were primiparous and multiparous, between three and six years old, and had a range of lactation from 60 to 232 days. Protein is the milk component that is least influenced by seasonal variation but is dependent on lactation duration and age. Research indicates that protein increases with prolonged lactation, and higher protein levels in milk tend to be produced from cows over seven years old compared with protein levels in milk from primiparous animals. Milk protein levels can also be affected by the lactation stage, being lower in the first three months, and increasing progressively as lactation continues (LACERDA et al., 2014). However, it is important to mention that even though there was a difference between the groups in this study, both groups maintained minimum protein parameters during the study, as recommended by IN 76 of 2018 (MAPA, 2018). Nevertheless, in a study on Holstein cow's milk production and quality attributes according to calving order, SOUZA et al. (2010) did not find any significant effect in the number of lactation days on protein level, with a mean value of $3.23 \%$.

We also observed that the protein level gradually increased in milk from GII cows (Figure 1e), especially in the second phase of the study. This increase in milk quality enhances product shelflife as well as providing a higher yield to the dairy industry. Milk proteins are one of the most beneficial constituents in milk, for both digestibility and the high nutritional value of essential amino acids (GONZÁLES et al., 2011). Milk protein levels were increased on day 30 in the GI group, indicating an increase in the lactose content (Figure 1e). It should be noted that lactose is one of the milk constituents with low oscillation, but a high osmotic capacity. Decrease in lactose levels implies lower milk production. Therefore, in a healthy mammary gland, greater lactose secretion results in greater milk volume production (BOTARO et al., 2011). In relation to lactose levels, there was no difference between GI and GII $(\mathrm{P}=0.784)$. Therefore, our results are different from those of KUNG et al. (2008), who replaced antibiotics and ionophores in ruminant feed with a blend of essential oils to produce positive changes to the physico-chemical properties of milk.

Table 3 and figure 2 show the biochemical profile of cow milk in this study. The phytogenic additives used had a positive effect on the AST level $(\mathrm{P}=0.019)$. GII presented parameters that characterize clinically healthy animals. AST is an important metabolic energy indicator that is used to indicate metabolic problems related to compromised nutritional status of dairy cattle. Normal AST levels indicate a healthy animal (KANEKO et al., 2008).

The high activity of AST in the liver of dairy cows leads to increased serum AST levels indicating that the liver functions are compromised, in acute or chronic forms. However, there is no simple specific or direct method to identify the reason for the increase in serum AST because its activity could be increased due to muscle, renal, and pancreatic cell

Table 3 - Serum biochemical analyses for aspartate aminotransferase (AST), urea, cholesterol, gamma-glutamyl transferase (GGT), and creatinine in Holstein cow milk from the control group (GI) and supplemented with phytogenic additives based on cardol, cardanol, and ricinoleic acid (GII).

\begin{tabular}{lcccc}
\hline Variant & Group & Mean & SEM & Groups x Time \\
\hline & & & & 0.674 \\
AST $\left(\mathrm{U} \mathrm{L}^{-1}\right)$ & GI & $105.070^{\mathrm{a}}$ & 4.983 & 0.019 \\
& GII & $88.012^{\mathrm{b}}$ & 5.119 & 0.670 \\
Urea $\left(\mathrm{mg} \mathrm{dL}^{-1}\right)$ & GI & 31.450 & 2.122 & 0.724 \\
Cholesterol $\left(\mathrm{mg} \mathrm{dL}^{-1}\right)$ & GII & 26.944 & 2.180 & 0.141 \\
& GI & 136.3 & 8.671 & 0.430 \\
GGT $\left(\mathrm{U} \mathrm{L}^{-1}\right)$ & GII & 146.21 & 8.441 & 0.413 \\
Creatinine $\left(\mathrm{mg} \mathrm{dL}^{-1}\right)$ & GI & 33.909 & 1.998 & 0.757 \\
\hline
\end{tabular}

SEM: standard error of the mean. Different letters indicate significant differences between groups $(\mathrm{P}<0.05)$.

Ciência Rural, v.51, n.12, 2021. 


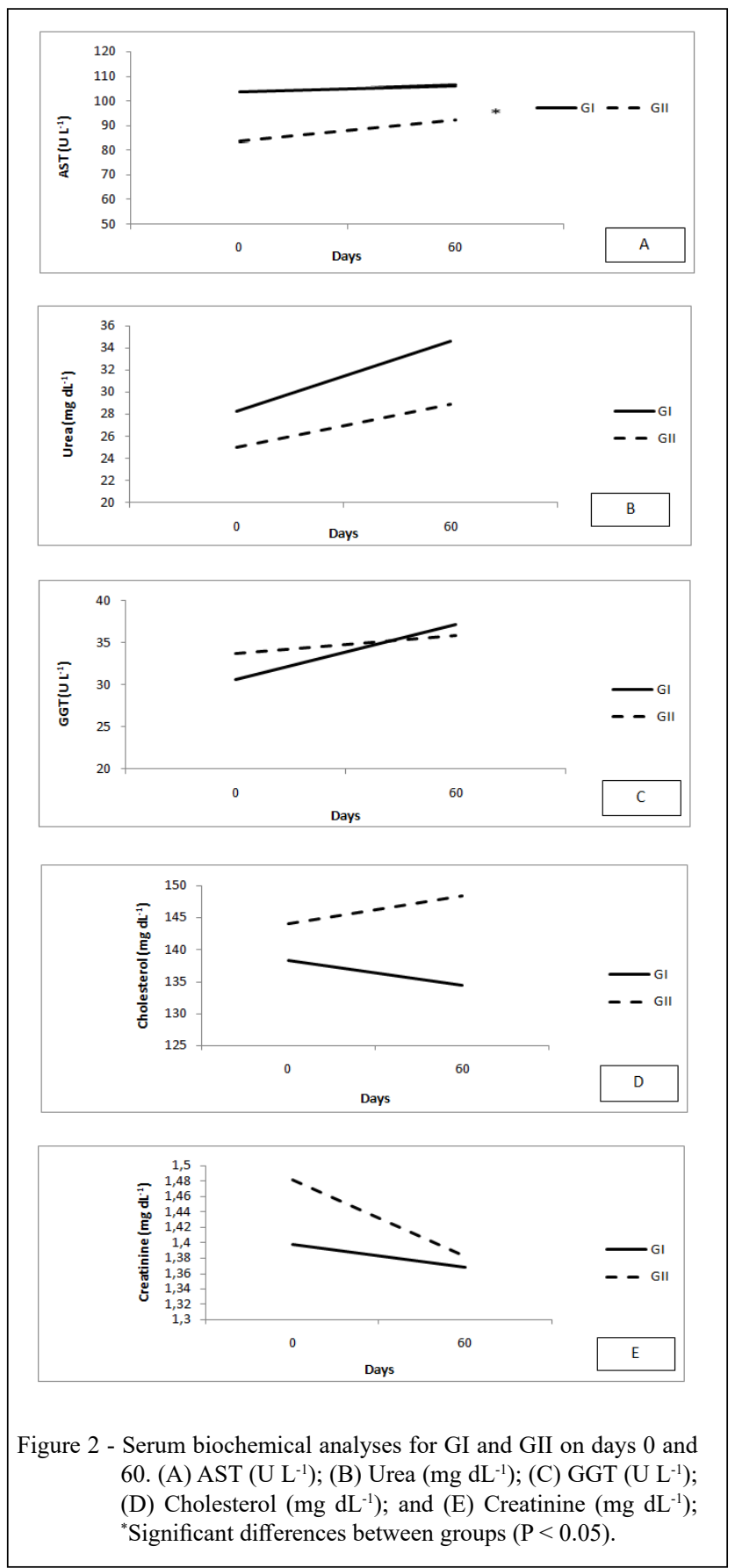

injuries (KANEKO et al., 2008). AST has a positive correlation with mammary gland activity as well as liver and heart problems. Changes in liver function due to hepatic fatty infiltration in dairy cows are associated with increases in AST concentrations (LAGO et al., 2001). In this study, the serum AST level was significantly different in GII animals compared with that in GI animals (88.012 $\mathrm{U} \mathrm{L}^{-1}$ and 105.070, respectively, $\mathrm{P}=0.019)$. These data are shown in Table 3 and Figure 2a, and are considered normal according to the serum biochemical standards for dairy cattle, indicating that the animals are clinically healthy. AST is an important marker for hepatic and metabolic functions. Therefore, in this study, the 
phytogenic additives had a positive effect because there was no evidence of liver function alteration that would compromise both the cattle's health and productivity. There were no differences between the control and treatment groups for the rest of the serum parameters evaluated, based on the specified species reference values.

\section{CONCLUSION}

This study demonstrated that the addition of phytogenic additive modulating rumen fermentation based on cardol, cardanol and ricinoleic acid does not compromise, in general, the quality of milk, with positive results for some specific parameters such as protein content and aminotransferase and may have contributed to the decrease in SCC of milk from Holstein cows.

\section{ACKNOWLEDGEMENTS}

This research did not receive any specific grant from funding agencies in the public, commercial, or not-forprofit sectors.

\section{DECLARATION OF CONFLICT OF INTEREST}

The authors declare no conflict of interest. The founding sponsors had no role in the design of the study; in the collection, analyses, or interpretation of data; in the writing of the manuscript, and in the decision to publish the results.

\section{AUTHORS' CONTRIBUTIONS}

All authors contributed equally for the conception and writing of the manuscript. All authors critically revised the manuscript and approved of the final version.

\section{BIOETHICS AND BIOSSECURITY COMMITTEE APPROVAL}

This study was approved by the Animal Ethics Committee of the Universidade do Oeste de Santa Catarina (UNOESC) under protocol No. 058/2018.

\section{REFERENCES}

BENCHAAR, C. Diet supplementation with cinnamon oil, cinnamaldehyde, or monensin does not reduce enteric methane production of dairy cows. Animal, v.10, n.3, p.418- 425, 2016. Available from: <https://pubmed.ncbi.nlm.nih.gov/26888487/>. Accessed: Nov. 23, 2019. doi: 10.1017/S175173111500230X.

BENCHAAR, C. et al. Effects of addition of essencial oils and monensin premix on digestion, ruminal fermentation, milk production, and milk composition in dairy cows. Journal of Dairy Science, v.89, p.4352-4364, 2006. Available from: $<$ https://www.journalofdairyscience.org/action/showPdf?pii $=$ S0022-0302\%2806\%2972482-1>. Accessed: Jan. 22, 2021. doi: 10.3168/jds.S0022-0302(06)72482-1.

BENCHAAR, C. et al. Effect of essential oils on digestion, ruminal fermentation, rumen microbial populations, milk production, and milk composition in dairy cows fed alfafa silage or corn silage. Journal of Dairy Science, v.90, p.886-897, 2007. Available from: <https://www.journalofdairyscience.org/action/showPdf?pii $=$ S0022-0302\%2807\%2971572-2> Accessed: Jan. 22, 2021. doi: $10.3168 /$ jds.S0022-0302(07)71572-2.

BORNEO, R.; AGUIRRE, A. Chemical composition, cooking quality, and consumer acceptance of pasta made with dried amaranth leaves flour. LWT-Food Science and Technology, v.41, n.10, p.1748-1751, 2008. Available from: $<$ https://www.sciencedirect. com/science/article/pii/S0023643808000583?via\%3>. Accessed: Aug. 10, 2019. doi: 10.1016/j.lwt.2008.02.011.

BOTARO, B. G. et al. Protein composition and milk fractions from commercial cattle herds. Veterinária e Zootecnia, v.18, n.1, p.8191, 2011. Available from: <https://www.bvs-vet.org.br/vetindex/ periodicos/veterinaria-e-zootecnia/18-(2011)-1/composicao-efracoes-proteicas-do-leite-de-rebanhos-bovinos-comerciais/>. Accessed: Jun. 23, 2019.

BOX, G.E.P; COX, D. R. An analysis of transformations. Journal of the Royal Statistical Society: Series B (Methodological), v.26, n.2, p.211-243, 1964. Available from: https://www.ime.usp. br/ abe/lista/pdfQWaCMboK68.pdf. Accessed: Feb. 04, 2021.

CALSAMIGLIA, S. et al. Invited review: essential oils as modifiers of rumen microbial fermentation. Journal of Dairy Science, v.90, n.6, p.2580-2595, 2007. Available from: <file://C:/Users/gilgi/ Downloads/2580.pdf >. Accessed: Jun. 15, 2018. doi: 10.3168/ jds.2006-644.

CODY, R. An introduction to SAS university edition. [S.1.]: SAS Institute, 2018.

CRUZ, O. T. B. et al. Effect of glycerine and essential oils (Anacardium occidentale and Ricinus communis) on animal performance, feed efficiency and carcass characteristics of crossbred bulls finished in a feedlot system. Italian Journal of Animal Science, v.13, p.790- 797, 2014. Available from: $<$ https:// www.tandfonline.com/doi/pdf/10.4081/ijas.2014.3492?needAcces $\mathrm{s}=$ true $>$. Accessed: Jan. 15, 2021. doi.org/10.4081/ijas.2014.3492.

DO PRADO, R. M. et al. Milk yield, milk composition, and hepatic lipid metabolism in transition dairy cows fed flaxseed or linola. Journal of dairy science, v.99, n.11, p.8831-8846, 2016. Available from: <https://www-sciencedirect.ez225.periodicos. capes.gov.br/science/article/pii/S0022030216306099?via\%3>. Accessed: Jul. 27, 2019. doi: 10.3168/jds.2016-11003.

DUFFIELD, T. F.; et al.,A meta-analysis of the impact of monensin in lactating dairy cattle. Part 2. Production effects. Journal of Dairy Science, v.91, p.1347-1360, 2008. Available from: <https://www. sciencedirect.com/science/article/pii/S002203020871261X>. Accessed: Jan. 18, 2021. doi:10.3168/jds.2007-0607.

FOOD AND AGRICULTURE ORGANIZATION OF THE UNITED NATIONS (FAO). Dairy Production and Products - Milk Production. 2016. Available from: <http://www.fao.org/agriculture/dairy- gateway/ milk-production/en/\#.V3AZwbgrLIV>Accessed: nov 24, 2019. 
GANDRA, J. R. et al. Productive performance of simmental dairy cows supplemented with ricinoleic acid from castor oil. Archivos de Zootecnia, v.63, n.244, p.1-10, 2014. Available from: <http:// scielo.isciii.es/pdf/azoo/v63n244/art2.pdf>. Accessed: Jan. 27, 2021. doi: 10.4321/S0004-05922014000400002.

GIANNENAS, I. et al. Effects of essential oils on milk production, milk composition, and rumen microbiota in Chios dairy ewes Journal of Dairy Science, v. 94, n.11, p.5569-5577, 2011. Available from: <https://www-sciencedirect.ez225.periodicos. capes.gov.br/science/article/pii/S0022030211005844?via\%3>. Accessed: Mar. 13, 2019. doi: 10.3168/jds.2010-4096.

GONZÁLES, F. H. D. et al. Qualidade do leite bovino, variações no trópico e subtrópico. Passo Fundo, p. 11-27, 2011.

GONZALEZ, S. G. et al. Influence of racial and nutritional management factors on somatic cells count and milk composition of Holstein and mixed breed cows in the north of Paraná State, Brazil. Acta Scientiarum. Animal Sciences, v.25, n.2, p.323-329, 2003. Available from: <http://www.periodicos.uem.br/ojs/index. php/ActaSciAnimSci/article/view/2016/1408>. Accessed: Sept. 10, 2019. doi: 10.4025/actascianimsci.v25i2.2016.

HAMAD, F. B.; MUBOFU, E. B. Potential biological applications of bio-based anacardic acids and their derivatives. International Journal of Molecular Sciences, v.16, n.4, p.8569-8590, 2015. Available from: <file://C:/Users/gilgi/Downloads/ijms-16-08569-v2. pdf>. Accessed: Nov. 04, 2019. doi: 10.3390/ijms16048569.

IPHARRAGUERRE， I. R.; CLARK， J. H. Usefulness of ionophores for lactating dairy cows: a review. Animal Feed Science and Technology, v.106, n.1-4, p.39-57, 2003. Available from: <https://www-sciencedirect.ez225.periodicos.capes.gov.br/ science/article/pii/S0377840103000658?via\%3>. Accessed: May, 07, 2019. doi: 10.1016/S0377-8401(03)00065-8.

JOUANY, J. P.; MORGAVI, D. P. Use of 'natural' products as alternatives to antibiotic feed additives in ruminant production. Animal, v.1, p.1443-1466, 2007. Available from: https://www. sciencedirect.com/science/article/pii/S1751731107000742. Accessed: Jan. 05, 2021. doi: 10.1017/S1751731107000742.

KANEKO, J. J.; et al.,Clinical biochemistry of domestic animals. [S.1.]: Academic press, 2008.

KHIAOSA-ARD, R.; ZEBELI, Q. Meta-analysis of the effects of essential oils and their bioactive compounds on rumen fermentation characteristics and feed efficiency in ruminants. Journal of Animal Science, v.91, p.1819-1830, 2013. Available from: https://pubmed.ncbi.nlm.nih.gov/23345564/. Accessed: Jan. 15, 2021. doi: 10.2527/jas.2012-5691.

KHOLIF, E. et al. Phytogenic feed additives mixture enhances the lactational performance, feed utilization and ruminal fermentation of Friesian cows. Animal Biotechnology, p.1-11, 2020. Available from: <https://www.tandfonline.com/doi/abs/10 $.1080 / 10495398.2020 .1746322>$. Accessed: Feb. 10, 2021. doi: $10.1080 / 10495398.2020 .1746322$.

KLEVENHUSEN, F. et al. A meta-analysis of effects of chemical composition of incubated diet and bioactive compounds on in vitro ruminal fermentation. Animal Feed Science and Technology, v.176, p.61-69, 2012. Available from: https://www.sciencedirect. com/science/article/abs/pii/S0377840112002416. Accessed: Feb 12, 2021. doi: 10.1016/j.anifeedsci.2012.07.008.
KOLLING, G. J. et al. Performance and methane emissions in dairy cows fed oregano and green tea extracts as feed additives. Journal of dairy science, 2018. v.101, n.5, p.4221-4234. Available from: <https://www-sciencedirect.ez225.periodicos.capes.gov.br/ science/article/pii/S002203021830153X?via\%3>. Accessed: Oct. 03, 2019. doi: $10.3168 /$ jds.2017-13841.

KUNG, L. JR. et al. A blend of essential plant oils used as an additive to alter silage fermentation or used as a feed additive for lactating dairy cows. Journal of dairy science,. v. 91, n. 12, p. 4793-4800, 2008. Available from: $<$ https://www-sciencedirect.ez225.periodicos. capes.gov.br/science/article/pii/S0022030208709457?via\%3>. Accessed: Oct. 15, 2019. doi: 10.3168/jds.2008-1402.

LACERDA, E. C. Q. et al. Effect of the dietary inclusion of dried oregano (Origanum vulgare L.) on the characteristics of milk from Holstein $\times$ Zebu cows. Animal Feed Science and Technology, v.192, p.101-105, 2014. Available from: <https:// www-sciencedirect.ez225.periodicos.capes.gov.br/science/article/ pii/S037784011400114X?via\%3>. Accessed: Sept. 13, 2019. doi: 10.1016/j.anifeedsci.2014.03.007.

LAGO, E. P. DO et al. Effect of body condition score at calving on energy metabolism, milk yield and disease occurence in postpartum of dairy cows. Revista Brasileira de Zootecnia, v.30, n.5, p.1544-1549, 2001. Available from: <https://www.scielo.br/ pdf/rbz/v30n5/6694.pdf>. Accessed: Aug. 10, 2019. doi: 10.1590/ S1516-35982001000600023.

MAPA, M. D. A. P. E. A. Instrução Normativa 76 e 77. INSTRUÇÃO NORMATIVA No 76, DE 26 DE NOVEMBRO DE 2018, [S.1.], 2018. Available from: <http://www.in.gov.br/ materia/-/asset_publisher/Kujrw0TZC2Mb/content/id/52750137/ do1-2018-11-30-instrucao-normativa-n-76-de-26-de-novembrode-2018-52749894IN 76>.

$\mathrm{OH}$, J. et al. Immune and production responses of dairy cows to postruminal supplementation with phytonutrients. Journal of Dairy Science, v.96, p.7830-7843, 2013. Available from: $<$ https:// www.sciencedirect.com/science/article/pii/S0022030213007182>. Accessed: Jan. 28, 2021. doi: 10.3168/jds.2013-7089.

$\mathrm{OH}$, J. et al. Effects of dietary Capsicum oleoresin on productivity and immune responses in lactating dairy cows. Journal of Dairy Science, v.98, p.6327-6339, 2015. Available from: <https://www. journalofdairyscience.org/article/S0022-0302(15)00492-0/pdf $>$. Accessed: Jan. 28, 2021. doi: 10.3168/jds.2014-9294.

PICININ, L.C.A. et al. Milk quality parameters associated with the occurrence of veterinary drug residues in bulk tank milk. Scientia Agricola, v.74, p.195-202, 2017. Available from: $\quad<$ https://www.scielo.br/scielo.php?script=sci arttext\&pi $\mathrm{d}=$ S0103-90162017000300195>. Accessed: Feb. 10, 2021. doi: $10.1590 / 1678-992 x-2016-0120$.

PRABHASANKAR, P. et al. Edible Japanese seaweed, wakame (Undaria pinnatifida) as an ingredient in pasta: Chemical, functional and structural evaluation. Food Chemistry, v.115, n.2, p.501-508, 2009. Available from: <https://wwwsciencedirect.ez225.periodicos.capes.gov.br/science/article/pii/ S0308814608014908?via\%3>. Accessed: Jul. 15, 2019. doi: 10.1016/j.foodchem.2008.12.047.

RODRIGUES, R. O. et al. Productive and physiological responses of lactating dairy cows supplemented with phytogenic feed ingredientes. Translational Animal Science, v.3, p.1133-1142, 
2019. doi: 10.1093/tas/txz108. Available from: <https://academic. oup.com/tas/article/3/4/1133/5530653>. Accessed: Feb. 12, 2021 doi: $10.1093 / \operatorname{tas} / \operatorname{txz} 108$.

SANTOS, M. V. Dos; FONSECA, L. F. L. Da. Controle da mastite e qualidade do leite - Desafios e Soluções. Pirassununga -SP: Edição dos autores, 2019. 301p.

SHINKAI, T. et al. Mitigation of methane production from cattle by feeding cashew nut shell liquid. Journal of Dairy Science, v.95, p.5308-5316, 2012. Available from: <https://pubmed.ncbi. nlm.nih.gov/22916936/> Accessed: Feb. 03, 2021. doi: 10.3168/ jds.2012-5554

SOUZA, R. De et al. Milk production and quality of Holstein cows in function of the season and calving order. Revista Brasileira de Saúde e Produção Animal, v.11, n.2, p.484-495, 2010. Available from: <http://revistas.ufba.br/index.php/rbspa/article/ view/1494/984>. Accessed: Aug. 12, 2019.

TORRES, A. et al. Germinated Cajanus cajan seeds as ingredients in pasta products: Chemical, biological and sensory evaluation Food Chemistry, v.101, n.1, p.202-211, 2007. Available from: $<$ https://www-sciencedirect.ez225.periodicos.capes.gov.br/
science/article/pii/S0308814606000744?via\%3>. Accessed: Jul. 23, 2019. doi: 10.1016/j.foodchem.2006.01.018.

TREVISAN, M. T. S. etal. Characterization of alkyl phenols in cashew (Anacardium occidentale) products and assay of their antioxidant capacity. Food and Chemical toxicology, 2006. v.44, n.2, p.188197. Available from: $<\mathrm{https} / / \mathrm{www}$-sciencedirect.ez225.periodicos. capes.gov.br/science/article/pii/S0278691505002243?via\%3>. Accessed: May, 05, 2019. doi: 10.1016/j.fct.2005.06.012.

VALERO, M. V et al. Feeding propolis or essential oils (cashew and castor) to bulls: performance, digestibility, and blood cell counts. Revista Colombiana de Ciencias Pecuarias, 2016. v.29, n.1, p.33-42. Available from: <https://www.researchgate. net/publication/292464737_Feeding_propolis_or_essential_oils Cashew_and_castor_to_bulls_Performance_digestibility_and blood_cell_counts>. Accessed: Nov. 12, 2019. doi: 10.17533/udea. recp.v29n1a04.

VIEIRA, C. et al. Effect of ricinoleic acid in acute and subchronic experimental models of inflammation. Mediators of inflammation, v.9, p.223-228, 2000. Available from: $<$ http://downloads.hindawi. com/journals/mi/2000/360629.pdf. $>$. Accessed: Sept. 23, 2019. doi: 10.1080/09629350020025737. 